reduced; there was less anaemia; and the reticulocyte count was considerably lower. Indeed, most of the 270 affected were completely asymptomatic and were found only in the course of population screening. Again the mildness of the disorder was ascribed mainly to the unusually high levels of $\mathrm{Hb} \mathrm{F}$.

Relatively large amounts of $\mathrm{Hb} F$ are also an advantage in the other common inherited disorder of haemoglobin production, beta-thalassaemia. Individuals who inherit a gene for persistent $\mathrm{Hb} \mathrm{F}$ synthesis in addition to that for beta-thalassaemia have much less severe anaemia than those who inherit only the thalassaemia. ${ }^{8}{ }^{9}$ Furthermore, those forms of beta-thalassaemia in which the molecular defect in haemoglobin synthesis itself results in increased $\mathrm{Hb} \mathrm{F}$ are generally milder than those in patients with limited $\mathrm{Hb} F$ production. ${ }^{10}$

If, then, relatively large amounts of $\mathrm{Hb} \mathrm{F}$ in adult life are so helpful to sufferers from sickle-cell anaemia and homozygous beta-thalassaemia, clearly we should be looking for some way to manipulate the normal switch from fetal to adult haemoglobin production that occurs about the time of birth. Unfortunately, we know virtually nothing about the mechanisms that control the switch. Indeed, it is not even clear why fetal haemoglobin persists at all in patients with sickle-cell anaemia or homozygous beta-thalassaemia. All normal adults continue to produce a few red cells that contain $\mathrm{Hb} \mathrm{F}$ ( $\mathrm{F}$ cells), and in sickle-cell anaemia and beta-thalassaemia the increased concentrations of $\mathrm{Hb} \mathrm{F}$ possibly reflect no more than simple selection of the normally occurring F-cell population during erythroid maturation or in the peripheral blood. ${ }^{11}$ Clearly, however, such cellular selection does not account for the very high concentrations of $\mathrm{Hb} \mathrm{F}$ found in Saudi Arabs with sickle-cell anaemia: some other genetic mechanism must be acting to cause an absolute increase in $\mathrm{Hb} \mathrm{F}$ production.

Research into the control mechanisms concerned in the change from fetal to adult haemoglobin is progressing, albeit slowly..$^{10}$ Several approaches are being explored, including detailed investigation of adults with genetically determined persistence of $\mathrm{Hb} \mathrm{F}$, study of the change from fetal to adult haemoglobin production in animals such as sheep and goats, ${ }^{12}$ and analysis of the interesting phenomenon whereby $\mathrm{Hb} \mathrm{F}$ synthesis can be reactivated in adult red cells maintained in tissue culture. ${ }^{13}{ }^{14} \mathrm{At}$ the moment none of these approaches has given any real insight into the precise mechanism of the control of haemoglobin switching, though evidently it relies on certain critical sites in the cluster of genes that determine the structure of the gammaand beta-chains of fetal and adult haemoglobin respectively. ${ }^{10}$ Shortly the new techniques of restriction mapping of $\mathrm{DNA}^{15}$ should be able to clarify the detailed structure of this area of the genome. Meanwhile we shall look forward to the results of further detailed genetic analysis of the remarkable Saudi Arab population.

The idea of being able to make therapeutic use of genes that are normally switched off during development is novel. Fetal haemoglobin is a perfectly adequate oxygen carrier in adult life; if its synthesis could be maintained after birth, even at a low level, we could control the distressing and frequently fatal clinical manifestations of both sickle-cell anaemia and betathalassaemia.

1 Serjeant, G R, The Clinical Features of Sickle Cell Disease. Amsterdam, North-Holland, 1974.

${ }^{2}$ Milner, P F, Clinics in Haematology, 1974, 3, 289

3 Perrine, R P, et al, Lancet, 1972, 2, 1163.

4 Singer, K, and Fisher, B, Blood, 1952, 7, 1216.

5 Bertles, J F, and Milner, P F, fournal of Clinical Investigation, 1968, 47, 1731.

6 Serjeant, G R, Clinics in Haematology, 1975, 4, 109.

${ }^{7}$ Perrine, R P, et al, Annals of Internal Medicine, 1978, 88, 1.

8 Wood, W G, et al, British fournal of Haematology, 1977, 36, 461.

9 Wood, W G, Weatherall, D J, and Clegg, J B, Nature, 1976, 264, 247.

10 Wood, W G, Clegg, J B, and Weatherall, D J, Progress in Hematology, $1977,10,43$.

11 Weatherall, D J, Clegg, J B, and Wood, W G, Lancet, 1976, 2, 660.
12 Wood, W G, et al, Nature, 1976, 164, 799.

${ }^{13}$ Papayannopoulou, T, Brice, M, and Stamatoyannopoulos, G, Proceedings of the National Academy of Sciences of the United States of America, 1977, 74, 2923.

14 Papayannopoulous, T, et al, Science, 1978, 199, 1349.

15 Jeffreys, A J, and Flavell, R A, Cell, 1977, 12, 429.

\section{"Proceed with the pricing"}

The CCHMS has achieved a satisfying result to the ballot on the new contract ( $\mathrm{p}$ 67). It confirms the favourable reception given to the proposals at the countrywide meetings of consultants addressed by the chairman of the committee and his senior colleagues. The 12308 valid votes cast, representing over $68^{\circ}{ }_{0}$ of the electorate, is a respectable response in a poll of this nature. With decisive majorities in the returns from each of the groups balloted-NHS contract holders and senior registrars voted $71^{\circ}{ }_{0}$ in favour, while honorary contract holders voted $3: 2$ in favourand with $50^{\circ}$ of all NHS contract holders supporting the new contract the CCHMS has an unarguable mandate to take the next step: to ask the Review Body to price the contract. Certainly a well-attended special meeting thought so when last week (p 67) it voted overwhelmingly - nem con with one abstentionto instruct the Negotiating Subcommittee "to proceed with the pricing exercise, taking into account all the relevant factors."

The BMA has been criticised for its conduct of the ballot (p 58). The background to the poll was given to the CCHMS at its meeting. To maintain an accurate roll of its own members' addresses and type of employment is not easy, for the BMA can depend only on the individual member to report changes of address or employment. To maintain a similar roll for the whole profession is even more problematical because non-members have no obligation to tell the BMA of such changes. Yet the Association is the only medical organisation which maintains a list of doctors classified by their employment and grade. To offset the list's known defects the BMA did two things : it obtained lists of staff in post from employing authorities to check against the Tavistock Square lists and it publicised widely invitations to eligible voters to apply directly for ballot papers if they had not received one. Given the imperfections of the electoral roll it is hardly surprising that some voting papers failed to reach their destination. But it is reasonable to assume that most arrived and that most of the 5700 non-voters either did not wish or perhaps could not be bothered to vote. That is an acknowledged hazard of elections and polls in a democratic society.

The CCHMS chairman, Mr A H Grabham, and the chairman of the Negotiating Subcommittee, Mr D E Bolt, have ably led the CCHMS over some formidable obstacles in the quest for improved pay and conditions of service for their constituents. ${ }^{1}$ It has also been an exemplary exercise in democracy. Yet the most difficult part of the course may well be the next few months. The Negotiating Subcommittee will have to prepare evidence to convince the Review Body-and the Government-that for the new work-sensitive contract to be effective will require more than a redistribution of consultants' present pay. Extra money is essential. Effecting a radical change of this complexity will not be easy (though criticising this or that part of the package will be all too easy) and CCHMS members understand consultants' wariness about the committee judging the final outcome without a further ballot. A good or bad result would present little problem, but last Thursday's discussion in the committee should reassure everyone that a ballot will be held if there are doubts. Meanwhile, consultants must trust their negotiators. So far, the CCHMS has done a difficult task democratically and commendably well: it deserves the profession's unwavering support during the coming months.

${ }^{1}$ British Medical fournal, 1978, 1, 1234. 